DOI: 10.32999/ksu2307-8030/2019-33-2

УДК 339.91:070

Poliakova Juliia

PhD in Economics, Associate Professor, Lviv University of Trade and Economics

Shaida Oksana

PhD in Economics, Associate Professor, Lviv University of Trade and Economics

Stepanov Andriy

Senior Teacher,

Lviv University of Trade and Economics

\title{
THE ROLE OF BUSINESS JOURNALISM IN MODERN INTERNATIONAL BUSINESS
}

The article is devoted to the study of the importance of business journalism for the development of international business in the global economy. The modern tendencies of the development of international business are systematised, and the significance and prospects for the use of business journalism tools are determined. The sectors producing the most popular business news are revealed. The functional purpose of the business press is considered in connection with forming the information environment of business development, and the main approaches to its classification are analysed. The role of business publications in advertising activity is estimated. The specific features and trends of the development of business publications in the modern global environment are singled out as well as the most common tools of corporate communication are identified. The transformation of business needs is considered in relation to the press, and the importance of business for the formation of the market of business publications is regarded.

Keywords: international journalism, globalisation, international business, international communication, business press, advertising.

ПоЛякова Ю.В., Шайда О.Е., СтеПаНОВ А.В. РОЛЬ ДЕЛОВОЙ ЖУРНАЛИСТИКИ В СОВРЕМЕННОМ МЕЖДУНАРОДНОМ БИЗНЕСЕ

Статья посвящена исследованию значения деловой журналистики для развития международного бизнеса в глобальной экономике. Систематизированы современные тенденции развития международного бизнеса, которые обуславливают важность и перспективность применения инструментов деловой журналистики. Выявлено секторы, производящие наиболее популярные новости сферы бизнеса. Рассмотрены функциональное назначение деловой прессы для формирования информационной среды развития бизнеса и основные подходы к её классификации. Оценена роль деловых изданий в рекламной деятельности. Выделены особенности и тренды развития деловых изданий в современной глобальной среде, наиболее распространенные инструменты корпоративной коммуникации. Рассмотрена трансформация потребностей бизнеса по отношению к прессе и значение бизнеса для формирования рынка деловых изданий.

Ключевые слова: международная журналистика, глобализация, международный бизнес, международные коммуникации, деловая пресса, реклама.

Полякова Ю.В., Шайда О.Є., Степанов А.В. РОЛЬ ДІЛОВОЇ ЖУРНАЛІСТИКИ У СУЧАСНОМУ МІЖНАРОДНОМУ БІЗНЕСІ

Стаття присвячена дослідженню ролі та значення ділової журналістики для розвитку міжнародного бізнесу у глобальній економіці. Систематизовано сучасні тенденції розвитку міжнародного бізнесу, які обумовлюють важливість і перспективність застосування традиційних та інноваційних інструментів ділової журналістики. Обґрунтовано характерні риси ділової журналістики як спеціалізованого складника медійного ринку, покликаного обслуговувати передусім інтереси осіб, що мають безпосереднє відношення до економічних і бізнес-процесів різних рівнів шляхом забезпечення відповідною інформацією. Розкрито поняття регіонального ділового видання, його значення для розвитку локального бізнес-середовища, пожвавлення підприємницької активності, формування цивілізованих інституціональних норм на місцевому рівні. Виявлено потужні сектори економіки, що виробляють найбільш популярні новини у сфері бізнесу. Розглянуто функціональне призначення ділової преси як джерела достовірної інформації для формування інформаційного середовища розвитку бізнесу та основні підходи до її класиффікації, зокрема поділ ділових видань на внутрішні і зовнішні; загальні, політико-економічні, політико-фінансові та біржові. Оцінено роль ділових видань у здійсненні рекламної діяльності з точки зору формування основних принципів роботи ділової преси та ризиків недотримання балансу між тематичними і рекламними матеріалами. Виокремлено особливості та новітні тренди розвитку універсальних та спеціалізованих ділових видань у сучасному глобальному середовищі та найбільш поширені інструменти корпоративної комунікації, зокрема тенденції розвитку ділових інтернет-видань. Розглянуто комплексну взаємодію бізнесу та преси - сучасні аспекти трансформації потреб бізнесу по відношенню до преси та значення бізнесу для формування ринку ділових видань.

Ключові слова: міжнародна журналістика, глобалізація, міжнародний бізнес, міжнародні комунікації, ділова преса, реклама.

Problem statement. The processes taking place in a globalised environment have a direct impact on the tendencies of international business development. Consequently, the media and business journalism become more important, as the international flow of information increases, new types of communication are used, and competition on the world markets of goods and services intensifies. Mass media are digitized, the process of integrating various technologies takes place, the information and communication system acquires the ability to respond and react to the actions of its user. At the same time, the tendencies of enlargement of the publishing business and its segmentation are manifested; profit oriented business models are modified; the market of Internet publications is expanded and the quality of the audience is altered. The role and significance of business communication tend to grow, while this type of communication is viewed as a professional interaction of subjects of the communicative process aimed at the commercial production and implementation of a competitive information product.

Analysis of recent studies and publications. Issues devoted to the development of business journalism and business communication have received extensive cov- 
erage in the scientific publications by domestic and foreign authors, including S. Vynohradova, O. Volodchenko, L. Dudchenko, S. Kulytskyi, H. Melnyk and others.

The research purpose of the article is to study the role of business journalism in the conditions of active development of international business under the influence of globalisation processes in the world economy.

Statement of the basic material and key research findings. Due to globalisation, entrepreneurs use different types of international activity, in distinct markets and segments, depending on their production, commercial, organisational, scientific and technical capabilities and aspirations. The success of using market strategies is conditioned not only by the availability of appropriate resources, the creation and implementation of business models, but also by information awareness about markets, terms and dynamics of their development, consumers' needs, "rules of the road".

As noted by domestic scientists, modern international business possesses the following features $[1, p .10]$ :

- increase of trade volumes under the influence of scientific and technological progress;

- intense processes of trans-nationalisation of the business sphere;

- globalisation of international business, when it covers the general system of information exchange, the global financial market and the global technological environment;

- deepening of the international division of labour and corresponding changes in the structure of goods and services in world trade;

- consolidation of close relations between domestic subjects of international business and foreign partners;

- taking into account factors of cross-cultural interaction when conducting business, that is, a set of requirements and restrictions imposed by the culture of a particular country;

establishment of technological connections between subjects of world business.

There is also an increase in the importance of qualitative and immediate information exchange with the help of modern information technologies and means of communication. In light of the foregoing, new approaches emerge to the functioning of business journalism as a kind of journalistic activity aimed at creating and ensuring the functioning of the media, designed to serve mainly the category of people involved in the economy and business. In the process of transformational changes, business journalism has become a high-quality communication tool for business and entrepreneurship, while at the same time serving as an important specialised player in the media market. Its formation was influenced by the revival of the business environment, the importance of informational support of business processes, the formation of institutional norms of conduct in world markets.

The business press is identified with a source of reliable business information. In particular, it creates an idea of international economic life, studies and monitors markets, places comments of professionals and experts, publishes analytical articles and reviews primarily designed for professionals, although the reader's audience noticeably tends to expand.

Nowadays, there is an emerging concept of a regional business edition, which is a publication in a certain territory of a particular country, intended for the business environment and publishing relevant information on business development and on the forma- tion of a favourable image of the business sector, both in the regions and in the whole country. The regional press, using the information resources of the region, in the most, approximates the business circles to the understanding of local needs, helps small and medium-sized businesses to take guidance in the internal business environment, makes up for the lack of local news, assures confidence by facilitating the coordination of interests of economic partners and encouraging them to cooperate, personifies economic relations, favours to minimize the risks of economic activity.

Business news are produced by the most popular sectors such as real estate, banking and finance, e-commerce, technology, retail sales, hotel business and tourism, logistics, transfer of intellectual property rights (franchising), agriculture, construction, insurance, motor transport, advertising, production.

A new concept of the business press emerges, which is understood as a special part of analytical specialised periodicals owing to its focus on a certain segment of society, namely, socially active people who are involved in the sphere of economic and business activity [2]. The business press is intended, if anything, for the formation of information environment for business development. That is, the business press carries out a functional purpose of informing about domestic and foreign news; presents an analysis of the main events in the country and the world in terms of their impact on business life; reports on the research of social problems connected with changes in the sphere of economy; detects the impact of operational commercial information on the economy; contributes to the formation of a business ideology. The business information sector covers economic, stock market, financial, statistical, commercial information and business news.

In scientific journals, the business press is classified depending on the audience, subjects and thematic orientation, the territory of distribution, the characteristics of the publishing house, etc. Thereafter, business media are subdivided into [3, p. 23]: general (publications keeping implicit features of the typological model, and distinguished by sufficient thematic versatility), political and economic (publications with a prevalent theoretical political and economic component, through which important social and political events are examined), political and financial (publications concerning the dynamics of bank capital, the actions of financial institutions, trends and specific features of lending, currency exchange rates, etc.), stock exchanges (editions, which reflect the features of stock-exchange life: sale and purchase of securities, stock quotes, etc.).

We also note that business publications are divided into internal: business-to-person (B2P), where the target audience is a company staff learning about the company's news and activities, which allows the team to improve their qualifications, increase their awareness and engage in corporate processes; external: business to business (B2B), aimed primarily at business partners in order to create a favourable image of the company in the business environment, to establish profitable contacts, and to find reliable partners; and business to customer (B2C), oriented to the company's customers who learn information about company novelties, customer care, manner and style of dealing with clients, personnel, promotions or contests.

According to scholars, business journals in Ukraine are aimed at the disclosure of mostly two types of knowledge [4]: procedural, i.e. publication of various laws and regulations, legal advice on certain situations in the field of entrepreneurship, that is, offering entre- 
preneurs appropriate schemes of behaviour in particular situations; declarative, which comprise reports about various events and their comments, thematic analyses, interviews, advertisements, announcements.

The most common tools for corporate communication are films, calendars, booklets, brochures, websites, newsletters, letters, leaflets, directories, books, newspapers, magazines.

Business press acts as a subject of advertising and is popular with serious advertisers. Since advertising in the business press operates mainly in the B2B mode, the main feature of the advertising object is the obligatory affiliation of the addressee of the advertisement to a particular business group. Based on this, the business publication is a significant subject of advertising, as it plays the role of a linking element between the customer and the manufacturer of advertising. As a result, the main principles of the business press were formed in the advertising market: active sales, flexible system of discounts, bonuses for advertisers, access to the target audience, professionalism. Business publications are intended to promote goods and services, support their image, and provide advertisers with access to solvent audiences [5]. However, business publications during their promotional activities are warned of not being trapped, as balancing when trying to satisfy the interests of advertisers can impair the publication, leading to a loss of audience and narrowing the market niche [6].

Business press is an integral part of business, and it is aimed not only at businessmen or managers, but also at those who want to raise awareness of information in a particular area. It can be noted that the press and business act as a kind of partnership contributing to the goal of increasing the competitiveness of business and the creation of independent quality business publications that stimulate the growth of business processes. Under the influence of economic processes, there are changes going on in the functional purpose of business press. Thus, among the most important functions the following are distinguished [7]: the spread of business excellence; expansion of business erudition; provision of a contact audience with the latest update of commercial news and special information on the properties of goods, services, production processes, technology; formation of a positive image of the enterprise in the minds of the audience; formation of business ideology; assistance in establishing business contacts; influence on the authorities in order to make decisions that should facilitate the establishment and development of business; provision of the audience with reliable information and reporting about the results of research on existing problems and achievements of scientific economic thought.

To our mind, the most noticeable modern trends in the development of business Internet publications are the following: the business models of online media are translated as videotext, paid internet, free web services, internet advertising, as well as general, individ- ual and multi portals; certain types of publications are expanding, among which one may find advisory business journals, corporate magazines, ads newspapers, specialised business overview and analytical publications, business publications of commercial organisations, universal observational and analytical weekly editions, daily business newspapers, analytical sectoral and branch-wise publications, etc.

The needs of business are also changed in relation to the press, which is revealed in the areas of providing information about products and services to customers, partners, society, government; solving problems of creating brands of a firm, commercialisation of brand products and services; formation of a positive image of domestic business; protection of the firm's interests in a competitive struggle in the context of real business practice; enhancement of objective coverage of the present state and trends of entrepreneurship development; attraction of public attention to real problems of entrepreneurship; coverage of issues related to new business technologies promoting small businesses and their new products in the advertising market; assessment of the state of affairs in the domestic and international markets.

Conclusions. Thus, the rapid development of globalisation and the corresponding growth of business require economic, analytical, marketing, and research activity in the modern business environment, which leads to the transformation of business journalism and increases its impact on the global and regional information markets. In such circumstances, the functions of the business press are reduced to informing about domestic and foreign news; exposing the modern style of business life; analysing the main events in the country and in the world in terms of their impact on business; covering social problems related to changes in the economy; detecting the impact of immediate commercial information on the economy; forming an ideology and a way of thinking by business categories.

\section{REFERENCES:}

1. Hutsaliuk O.M., Cherevatenko V.A. Development of international business in the context of international management. State and Regions. Series "Economics and Entrepreneurship". 2015. № 6. P. 8-13.

2. Dudchenko L.M. Classification of Business publications in the context of media typology as a scientific problem. State and Regions. Series "Social Communication". 2014. № 3. P. 68-72.

3. Melnyk H.S., Vynohradova S.M. Business journalism : Coursebook. Saint Petersburg : Piter, 2010. 304 p.

4. Kulytskyi S.P. On the segmentation of the market of business periodicals in Ukraine. Marketing in Ukraine. 2009. № 3. P. 60-64.

5. Miroshnychenko S.M. The subject and object of advertising in business publications of Ukraine. URL: http://www-philology.univer.kharkov.ua/ nauka/e_books/miroshnichenko.pdf (access date: 20.12.2018).

6. Rachynskyi S.A. Where does business journalism come from? URL: http://newmedia.in.ua/articles/aktualno/zvidki-beretsya-dilova-zhurnalistika.html (access date: 20.12.2018).

7. Volodchenko O.M. Realization of ethical standards in modern business journalism. URL: http://journlib.univ.kiev.ua/index. php?act=article=2289 (access date: 20.12 .2018$)$. 